\title{
A NEUROPSZICHOLÓGIA SZEREPE A GYÓGYPEDAGÓGIAI PSZICHODIAGNOSZTIKA MEGÚJULÁSÁBAN
}

\author{
GEREBEN FERENCNÉ
}

ELTE Bárczi Gusztáv Gyógypedagógiai Főiskolai Kar

Gyógypedagógiai Pszichológiai Intézet, Budapest

\begin{abstract}
A tanulmány áttekinti, hogy a neuropszichológiai diagnosztikai módszerek milyen szerepet játszanak a gyógypedagógiai munkában. A szerzo" részletesen tárgyalja a gyógypedagógiai diagnosztika különféle szempontjait, a topográfiai és a tartalmi funkcióanalízis elméleti hátterét. Bemutatásra kerülnek azok a nemzetközileg elismert neuropszichológiai vizsgáló módszerek, amelyeknek magyarországi adaptálását és a különféle gyermekcsoportokon történő kipróbálását megkezdték a Gyógypedagógiai Pszichológiai Intézet munkatársai.
\end{abstract}

Kulcsszavak: neuroposzichológia, diagnosztika, gyógypedagógiai fejlódés-neuropszichológia, tanulási zavar, vizsgáló módszerek, fejlödési zavarok

A viselkedés megismerésének és megértésének problémái évtizedek óta a pszichológia és a neveléstudomány érdeklődésének középpontjában állnak és összefüggenek a diagnosztika kérdéseivel.

A diagnosztika a pedagógiában más értelmet nyer, mint az orvostudományban, minthogy a nevelés és fejlesztés céljával összefüggő intellektuális, pszichikus tényezők állapotának, fejlettségi színvonalának meghatározását jelenti különböző eljárások, vizsgálatok segítségével. A pedagógia gyakorlatában az ún. diagnosztizáló mérés következtében nyílik lehetőség a fejlesztő beavatkozások megszervezésére.

A mentális, szociális, emocionális és pszichikus fejlődés veszélyeztetettsége, a fogyatékosság okozta izoláció veszélye, a fejlődés, a teljesítmény és a viselkedés zavarai, a fogyatékosság különböző formáit jellemző tünetek feltárása, továbbá ezek jellegének, mértékének megállapítása szükségszerűen erősítette a gyógypedagógián belül a gyógypedagógiai diagnosztika szerepét.

A diagnosztika a gyógypedagógia elméletéhez és gyakorlatához annak tudo- 
mánnyá válása óta szorosan kapcsolódik, a szaktudományi ismeretek gyarapodásával az elmúlt évtizedekben a gyógypedagógia egyik önálló területévé vált.

A gyógypedagógiai fejlesztés és nevelés folyamatát a fogyatékos (sérült, akadályozott, fejlődésükben zavart) gyermekek, fiatalok, illetve nemegyszer a felnöttek esetében is a speciális szükségletek felismerése és diagnosztizálása indítja el.

A gyógypedagógiai diagnosztika önálló ismeretrendszerének kialakulása nem választható el a gyógypedagógiai pszichológia hazai kialakulásától, százéves múltjától, abban szorosan gyökerezik.

A komplex gyógypedagógiai pszichológiai diagnózis fogalmát a Ranschburg-iskola alkotta meg annak alapján, hogy a fogyatékosságok és fejlődési zavarok megítélésének folyamatában a gyógypedagógiai segítségnyújtás feladatainak meghatározásakor nélkülözhetetlennek tartotta az aktuálisan észlelt állapot, az előélet, a pszichológiai, pedagógiai, valamint a kóreredet feltárását segítő orvosi vizsgálati eredmények összefüggéseinek elemzését. A gyógypedagógiai pszichológia olyan szemléleti alapról indult el a századfordulón, amely összhangban áll a mai kor diagnosztikus szemléletével, s magában hordja a jelen kor igényeit is kielégíteni képes fejlesztésirehabilitációs irányultságú diagnosztika felé történő elmozdulást.

A gyógypedagógiai diagnosztika gazdag lehetőséget kínál a speciális szükségletű népesség képességeinek megismeréséhez, a fejlesztési, társadalmi beilleszkedési lehetőségek feltételeinek javításához, amennyiben a diagnosztikus munka intézményi, személyi és tárgyi feltételei biztosítottak.

A diagnosztikus módszerek csak kompetens szakemberek, gyógypedagógiai pszichológusok, a fogyatékosság kérdéseiben járatos klinikai és pedagógiai pszichológusok, klinikai munkában járatos gyógypedagógusok, diagnosztikus teamek munkája révén, a szupervízió biztosította lehetőségek felhasználásával válhatnak a tényleges segítségnyújtás eszközévé.

A gyógypedagógiai diagnosztika területén folytatott kutatásnak ennek megfelelően elő kell segítenie a diagnosztikus repertoár folyamatos megújítását, a diagnosztikus munka szempontjainak, feltételeinek érvényesítését a közoktatás és az egészségügyi rehabilitáció, a gyermek- és felnőttellátás területén egyaránt.

A gyógypedagógiai pszichológia gyakorlatában az ép és zavart fejlődés elkülönítésére, a fogyatékosság mértékének, jellegének megállapítása céljára pszichometriai eljárások, informális tesztek, szürőeljárások széles skálája terjedt el és képezi a gyógypedagógiai pszichodiagnosztika eszköztárát.

Az utóbbi két évtizedben azonban túlnyomóan deficitorientált, a szelekció irányába ható jellegük miatt egyre több kritika érte a különböző vizsgáló módszereket, köztük azokat a hagyományos tesztpszichológiai eljárásokat, amelyek többek között az agyi károsodások következményeként létrejött mentális és kognitív funkciózavarok feltárásának eszközeiként ismertek.

A kritika megfogalmazódásához hozzájárult az is, hogy a pszichometriailag különböző $\mathrm{IQ}, \mathrm{PQ}, \mathrm{VQ}, \mathrm{RQ}$ teljesítménymutatókban kifejezett diagnosztikus eredmények mellett a vizsgálók gyakran teljesen elhanyagolták a viselkedés körülményeinek komplexitását, továbbá a számszerűsített globális mutatókra épülő diagnózisokat nehezen lehetett a gyakorlatban alkalmazni, ezek alapján aligha lehetett, illetve lehet differenciált terápiát és rehabilitációs tennivalókat megfogalmazni. 
A gyógypedagógiai pszichodiagnosztika gyakorlata - a klinikai pszichológiához hasonlóan - szükségszerüen kezdte igényelni, illetve napjainkban egyre kifejezettebben igényli olyan módszerek használatát, amelyek a terápiareleváns teljesítményleírások felé mozdulnak el, s a szenzomotoros, illetve kognitív fejlődési folyamatok, a tanulási teljesítmények, a szerzett organikus hátterủ funkciókiesések differenciált leírásával lehetőséget nyújtanak funkcionális diagnózis felállítására.

E folyamat részeként is indult meg az a szemléletváltozás a gyógypedagógiai pszichodiagnosztikában, amely a fejlesztési irányultságra helyezte a hangsúlyt, továbbá e folyamat részének tekinthető a funkcionális diagnózis felállításának nagyobb lehetőségét biztosító neuropszichológiai-diagnosztikai ismeretek megjelenése a fogyatékosságok és fejlődési zavarok pszichológiai kérdéseivel kapcsolatban.

Ezek a törekvések, amelyek a nemzetközi szakirodalomban és diagnosztikus gyakorlatban a hatvanas évektől növekvő módon vannak jelen, napjainkban a hazai gyógypedagógiai pszichodiagnosztikában elsősorban tudományos problémaként fogalmazódnak meg, s egyben irányt mutatnak a gyógypedagógiai pszichodiagnosztika számára újfajta szemléletmód kialakulásához, újfajta ismeretrendszer megjelenéséhez, a neuropszichológia irányába történő szükségszerủ elmozduláshoz.

A neuropszichológia nem egyszerűen a viselkedés egy dimenziójának pszichológiai hátterével foglalkozik, mint a fejlődés-, a beszéd- vagy a munkapszichológia. Mindamellett, hogy a pszichológia egyik sajátos, a hazai klinikai gyakorlatban kevéssé mủvelt területét jelenti, egyben a tudományos gondolkodás azon irányának is tekinthető, amely a pszichés funkciók és a központi idegrendszeri folyamatok működését feloldhatatlanul összetartozónak és egymásra utaltnak tekinti, következetesen és egyidejűleg kíséri figyelemmel a pszichés funkciók és az agyműködés kapcsolatát.

E kétirányú megközelítés alapján a neuropszichológia „védőszárnya” alatt együtt található több társtudomány, így a neurológia, a pszichológia, a gyógypedagógiai pszichológia és a pszichodiagnosztika ismeretrendszere.

Ez a megközelítés annak a lehetőségét hordozza, hogy bizonyos kórformák, nehezen értelmezhetô teljesítményproblémák, klinikai képek esetén nagyobb biztonsággal válik lehetővé a felmerülő klinikai kérdések tisztázása, diagnosztikus dilemmák megoldása.

A neuropszichológia ismeretrendszerének erösödése a gyógypedagógiai pszichológiában tehát nem egy új divathullám megjelenésével függ össze, hanem egy nagy múltú, az agykutatás és a pszichológia eredményeit folyamatosan integráló, kevéssé hasznositott ismeretrendszer alkalmazását jelenti.

A neuropszichológiai diagnosztika a cerebrális funkciók vizsgálatán alapul azzal a céllal, hogy feltárja a funkcionális rendszerek működését, zavarait, az ép és sérült funkciók viszonyát, megállapítsa az egyénre jellemző működés aktuális sajátosságait az egyén jelenlegi és lehetséges jövőbeni viselkedésével összefüggésben.

Klinikai alkalmazási területe - egybeesően bizonyos gyógypedagógiai pszichológiai problémák diagnosztikus kérdéseinek megoldásával - sokszínú: 
- egyes klinikai képek, mint például az afáziák, agnóziák, emlékezeti zavarok, részfunkciózavarok, köztük a gyermekkorban igen nagy gyakorisággal, részképességzavarok bázisán kialakuló fejlődési zavarok, másképpen „diszjelenségek” (diszfázia, diszlália, diszlexia, diszgráfia, diszkalkúlia) neuropszichológiai tüneteinek elemzése;

- a fentieken túl az állapotjellemzők ismeretében tanácsadás az érintett és környezete számára;

- valamint a rehabilitációs tennivalók megtervezése és értékelése.

A neuropszichológiai diagnosztika tehát egyben a rehabilitáció bázisa. Bár a probléma feltárásának módját illetően sok hasonlóságot mutat a fejlesztés irányultságú gyógypedagógiai pszichodiagnosztikával, más jellegű, mélyebb szintű megismerésre ad lehetőséget.

A neuropszichológiai diagnosztika módszertani alapja a szindrómaanalízis, amely a teljes klinikai kép figyelembevételén alapul, a fogyatékosság, a sérült állapot tüneteinek feltárását hatékonyan segítheti elő. A klinikai kép feltárásához, valamint a majdani rehabilitációs kilátások megfogalmazásához nem elegendő magának a sérült funkciónak a vizsgálata.

Olyan tünetek esetén, amelyek például az afáziára vagy a diszlexia meglétére utalnak, a nyelven kívüli kognitív folyamatok, a mozgásszabályozás, a teljes cselekvés irányítása, a tanult ismeretek alkalmazásának képessége, valamint az emocionalitás megismerése egyaránt része kell hogy legyen a teljes klinikai kép feltárásának, figyelemmel olyan faktorokra, mint a gyógypedagógiai pszichodiagnosztika szempontjából is kiemelten fontos anamnézis, a kor, a nem, a nevelés és a környezet, valamint a premorbid személyiség és ezek lehetséges összefüggései a funkciók működésével.

A feltárás folyamatában hangsúlyos szerepet játszik:

- a funkciózavarra jellemző tünetek minőségi elemzése;

- a funkciókiesések mértékének meghatározása és

- a kompenzáció lehetőségeinek figyelembevétele.

A szindrómaanalízis alapján végzett vizsgálatokban többféle válaszlehetőség rejlik. A topográfiai jellegü funkcióanalizis esetén, amely a neurológia korszerủ módszereit is felhasználja, tisztázódhat, hogy

- van-e bizonyíték egyáltalán funkcionális zavar fennállására;

- melyek az érintett és melyek a müködőképes területek;

- diffúz vagy lokális, egyoldali vagy bilaterális jellegű, jobb vagy bal féltekei működési zavar áll-e fenn?

A tartalmi funkcióanalizis elősegítheti annak tisztázását, hogy hogyan függenek öszsze egymással például az emlékezeti, a nyelvi, illetve a vizuo-konstruktív folyamatok zavarai: 
- van-e és mi a szerepe a másodlagos reakcióknak a vizsgált személy és környezete kapcsolatában, mint például sajátos viszony az állapothoz, szembesülés a realitással, érzelmi krízis stb. Mindezek alapján megfogalmazásra kerülnek a gyakorlati tennivalók

- intézmény-, munkahely-változtatásra, fejlesztésre, rehabilitációra vonatkozó terv kialakítása, intézkedések - mint például kognitív terápia, pszichoterápia, családterápia - meghozatala vagy a környezeti feltételek módosítása az egyén szükségleteinek megfelelően.

A klinikai neuropszichológia és a gyógypedagógiai pszichológia tevékenységi területe több szálon kapcsolódik össze, mivel vizsgálódásuk tárgya, egyes klinikai képek tárgyalása, feltárása, megközelítésük módja részben egybeesik.

A neuropszichológiai gondolkodás középpontjában a felnőtt- és gyermekkorban egyaránt kialakuló ún. veszteségszindrómák, illetve a gyermekkorra jellemző, részfunkciózavarokban, disz-jelenségekben, a gyermekkori fejlődési zavarok különböző megjelenési formáiban felismerhető ún. felépülési szindrómák állnak.

Ez utóbbiakkal kapcsolatban ma még igen sok kérdés tisztázása vár a tudományos kutatásra. Az agyi sérülés kihatásai felnőttnél és gyermeknél eltérőek, gyermekeknél kevéssé körülírtak, diffúzak, kevéssé lokalizáltak. A funkciókieséseket könnyebb diagnosztizálni akkor, ha a funkció már kialakult, fejlődése lezárult, mint amikor még a dinamikus átalakulás stádiumában van. Egy még kialakulatlan funkció további fejlődése olyan irányt vehet, hogy egyes esetekben nehéz igazolni a sérülés tényét a megváltozott fejlődés folyamatában.

A neuropszichológiai diagnosztika alapvetően felnőttekre kidolgozott módszereit éppen ezért gyermekek vizsgálatában kevéssé lehet alkalmazni.

A túlnyomóan felnőttkori problémák feltárását segítő neuropszichológiai diagnosztikában az elmúlt évtizedben olyan új vizsgálóeljárások is megjelentek a gyakorlatban, amelyeket - fejlődés-neuropszichológiai megalapozottságuknál fogva gyermekek vizsgálatában igen jól lehet alkalmazni a funkcionális diagnózis felállítására és az egyéni fejlesztés tervezésére.

Ezek a felismerések is vezették a Gyógypedagógiai Pszichológiai Intézetet, amikor a Fefa-II, a Soros Alapítvány és a $\mathrm{K}+\mathrm{F}$ pályázatos programok keretében megkezdte a gyógypedagógiai pszichodiagnosztikai inventár korszerűsítését, olyan vizsgálóeljárások megismerését, adaptálását és különböző gyermekcsoportokon történő klinikai kipróbálását, amelyeket a neuropszichológiai diagnosztika nemzetközileg elismert és bevált módszerei között tartanak számon a gyermekvizsgálatok távolról sem lezárt kérdéseinek részeként.

Ezek közé tartozik:

- a Dél-kaliforniai szenzoros integrációs teszt - SIT ( AYRES, 1972)

- a Szenzoros integrációs praxis teszt - SIPT (AYRES, 1989)

- a Szenzoros integrációs teszt 0-18 hónapos korúaknak - TSFI (DEGANGI, GREENSPAIN, 1993)

- a Szenzoros integrációs teszt 3-5 éveseknek - TSI (DEGANGI, BERK, 1983) 
- a Célzott megfigyelések szenzoros integrációs zavarok felismerésére (PRINCE, SCHAEFGEN, 1995)

- a Tübingeni Lurija-Christensen neuropszichológiai teszt - TÜKI (DEEgEnER, DieTEl, KASSEL, MATTHAEI, NÖDL, 1992)

- a Lurija-Nebrasca neuropszichológiai tesztsorozat (GOLDEN, 1991)

A fenti eljárások jelenleg a kísérleti alkalmazás szakaszában vannak. Az összegyűlt tapasztalatok alapján azonban elmondható, hogy új lehetőségeket kínálnak a fejlődési zavarok felismerésében, a speciális nevelési szükségletű gyermekek fejlődési esélyeinek megítélésében.

A gyógypedagógiai pszichodiagnosztikában az ép és fogyatékos állapot elkülönítése céljából, differenciáldiagnosztikai és fejlesztésdiagnosztikai szempontból egyaránt jelentős szerepet játszik az intelligenciadiagnosztika. A jól ismert intelligenciavizsgáló eljárások között (Budapesti Binet, a Raven, a Snijdes-Oomen teszt) külön figyelmet érdemel a HAWIK teszt korszerűsített változata, a MAWGYI-R néven ismertté vált intelligenciavizsgáló eljárás magyar adaptációja, amely igen alkalmas arra, hogy az intelligenciadiagnosztika eredményeit a hagyományostól eltérő interpretálás helyett a fenti módszer felhasználásával új megvilágításba helyezze.

A topográfiai funkcióanalízist segítheti elő olyan pszichológiai vizsgálóeljárások alkalmazása, amelyek például a nyelvi intelligencia és az emlékezet kapcsolatát, a szintaxis, a szótalálás vagy az olvasás-írás teljesítmények, illetve a vizuokonstruktív folyamatok működésének zavarait tárják fel. A MAWGYI-R tesztben nyújtott teljesítmény alapján ezért, a verbális és performációs kvóciensek arányának ismeretében, a fentiek értelmében egyúttal a két félteke funkcionális működésbeli különbsége is kifejeződik. A bal félteke működési zavarait alacsony $\mathrm{VQ}$ és magas $\mathrm{PQ}$ jellemzi. A szubtesztek síkján tett összehasonlításból pedig kitűnik, hogy ez esetben a növekvő és csökkenő számsorok utánmondása, a szókincs próbája, illetve a számtani gondolkodás feladatai fokozott nehézséggel és alulteljesítéssel járnak.

A jobb félteke mủködési zavara esetén ugyanakkor ennek fordítottja, alacsony PQ és magas VQ figyelhető meg. A szubtesztek között feltűnő nehézségekkel járhat a képrendezés, az összeillesztés és a mozaikpróba feladatainak teljesítése.

A verbális és performációs teljesítmények különbségének értékelése, az eltérés mértékének, az alulteljesítések és teljesítményelőnyök figyelembevétele a funkcionális múködés sajátos, egyéni eltéréseire, a zavar topográfiájára, a kompenzációban részt vevő funkciókra s nem utolsósorban a terápia jellegének meghatározására is felhívják a figyelmet.

A teljes klinikai kép felállítását segíti továbbá a viselkedésbeli megnyilvánulások, emocionális reakciók elemzése is. A katasztrófareakciókkal jellemezhető depressziós, félelemre, szorongásra utaló diszfóriás viselkedés a bal, a differenciálatlan érzelmi megnyilvánulások, a beszédmoduláció, a gesztus és mimika terén mutatkozó csökkent kifejezőkészség a jobb félteke funkcionális működési zavarát jelzi. 
A fentiek természetesen csak töredékét fejezik ki annak a gazdag kínálatnak, amelyet a neuropszichológia ismereteinek, újabb technikáinak, s nem utolsósorban szemléletének érvényesítése jelent a gyógypedagógiai pszichodiagnosztika területén. A diagnosztikának ez az útja - a különös tekintettel a fejlődési zavarok és a gyermekkorban fellépő agyi károsodások kérdéseire - a megkezdett kutatások folytatását, különböző szakembercsoportok hatékony együttműködését teszi szükségessé, s egyúttal lehetőséget nyújt az emberi viselkedés mélyebb megismeréséhez.

\section{IRODALOM}

Ayres, A. J. (1972) Southern California Sensory Integration Tests. Western Psychological Services, Los Angeles

Ayres, A. J. (1989) Sensory Integration and Praxis Tests. Western Psychological Services, Los Angeles

Breitenbach, E. (1996) Auf neuen Pfaden zu alten (sonder-) pädagogischen Prinzipien. Neuropsychologische Aspekte von Lernen und Lernstörungen. Zeitschrift für Heilpädagogik, 10, 408-419.

Deegener, G., Dietel, B., Kassel, H., Matthaei, R., Nödl, H. (1992) Tübingener neuropsychologische Testbatterie. Beltz Test, Weinheim

DeGangi, G. A., Berk, R.A. (1983) Test of Sensory Integration. Western Psychological Services, Los Angeles

DeGangi, G. A., Greenspain, S. I. (1993) Test of Sensory Functions in Infants. Western Psychological Services, Los Angeles

Dietel, B., Kassel, H. (1993) Diagnostik von Teilleistungsstörungen. Neurolinguistischpsycholinguistisch orientierte Diagnose und Therapie von Lese-Rechtschreibschwachen. Zeitschrift für Heilpädagogik, 5, 297-316.

Fischer, A. G., Murray, E. A., Bundy, A. C. (1999) Sensorische Integrationstherapie. Springer Verlag, Berlin-Heidelberg-New York

GEREBEN FERENCNÉ (1998) Részképességzavarok - munkamodell a gyógypedagógia számára. Gyógypedagógiai Szemle, Különszám, 26-36.

Golden, CH. J. (1991) Screening Test for the Lurija-Nebrasca Neuropsychological Battery. Adults and Childrens Forms. Western Psychological Services, Los Angeles

Prince, A., Schaefgen, R. (1995) Gezielte Beobachtungen zur sensorischen Integration. Pro praxis, Bergen

Springer, S. P., Deutsch, G. (1993) Linkes Rechtes Gehirn. Spektrum Verlag, HeidelbergBerlin-Oxford 


\section{NEUROPSYCHOLOGICAL DIAGNOSIS IN THERAPEUTIC PEDAGOGY}

GEREBEN, FERENCNÉ

The paper reviews the role of neuropsychological diagnosis in therapeutic pedagogy. The author presents a detailed analysis of the methodology of therapeutic pedagogy, and the theoretical background of topographical and contain-based function-analysis. Internationally acknowledged neuropsychological tests are introduced for which adaptation process has just begun with Hungarian children by the Therapeutic Pedagogy Institute.

Key words: neuropsychology, diagnostic, special education, developmental neuropsychology, learning disabilities, diagnostic tests, disorders of development 